\title{
Restorative Justice as a Resolution for the Crime of Rape with Child Perpetrators
}

\author{
Edhei Sulistyo", Pujiyono and Nur Rochaeti
}

\author{
Faculty of Law, Universitas Diponegoro, Semarang City, Imam Bardjo SH Street No. 1, Pleburan, Semarang \\ City, 50241, Indonesia
}

\begin{abstract}
A child who commits a criminal act can be called a child in conflict with the law. One of the crimes committed by children was rape, which involved elementary and junior high school children in Probolinggo; they reportedly raped a high school student until they became pregnant. Sexual crimes against children occur in Southeast Asian countries, such as the Philippines, Thailand, Sri Lanka, Malaysia, and Indonesia. The purpose of this study was to review restorative justice as an effort to resolve the criminal act of rape with child perpetrators. The research method used is normative juridical research, with the approach of laws and concepts and collecting primary legal material in the form of existing cases. This study found that the restorative justice process in juvenile crime is essential because there are essential things to focus on the regulation that requires the active role of the community, perpetrators, and victims of crime, including the affected community, in the restorative justice process. A fundamental balancing approach must also be taken, namely, first, imposing sanctions based on responsibility for recovering victims' losses as a consequence of criminal acts; second, rehabilitation and reintegration of actors; and third, strengthening community safety and security systems.
\end{abstract}

Keywords: Restorative Justice, Resolution, Crime, Child Perpetrators.

\section{INTRODUCTION}

Children are an inseparable part of the sustainability of human life and the sustainability of a nation and a State. In the Indonesian constitution, children have a strategic role, which explicitly states that the state guarantees every child's right to live, grow and develop, and protect from violence and discrimination (Pramukti \& Primaharsya, 2014).

Children can also be the nation's next generation and the successor to the current development struggles. Children are both a mandate and a gift from God Almighty, which we must always protect because they are inherent in their dignity, dignity, and human rights that must be upheld. Child human rights are part of the human rights contained in the 1945 Constitution and the United Nations Convention on the Child's Rights. In terms of national and state life, children are the future of the nation and the next generation of the ideals of the nation, so that every child has the right to survive, grow and develop to participate and be entitled to protection from acts of violence and discrimination as well as civil rights and freedoms. Even though children's rights have been guaranteed in various laws and regulations, children still must carry out ethics and have noble morals as a form of social error that makes the relationship between the child and the child and their parents' orderly shows an attitude towards them.

*Address correspondence to this author at the Faculty of Law, Universitas Diponegoro, Semarang City, Imam Bardjo SH Street No. 1, Pleburan, Semarang City, 50241, Indonesia; E-mail: edheisulistyo@gmail.com
Akhlak is an institution that comes from the heart, where voluntary actions, right or wrong actions, arise (Jamil, 2013).

Along with the rapid development of technology, children no longer behave like children but have started to behave like adults. This can be due to the possibility that the child lacks or does not get affection, care, and guidance as well as guidance in the development of adaptive behavior attitudes, as well as supervision from parents, guardians, or foster parents so that they are quickly dragged into the flow of social relations and their unhealthy environment. Detrimental to his personal development (Supramono, 2010).

Due to the influence of the surrounding conditions, children often participate in criminal acts. It can be caused by persuasion, spontaneity, or just being a part of it. Even so, it is still a criminal act. However, for the sake of children's mental growth and development, it is necessary to pay attention to the differentiation of treatment in procedural law and criminal threats (Hutahaean, 2013).

The term criminal offense is a term officially used in Indonesian laws and regulations. In Indonesian criminal law experts' writings, sometimes the term offense is used as an equivalent to the term criminal offense. The term offense comes from the word "delict" in Dutch (Sjahdein, 2017). Some use the term criminal offense for criminal acts. The term was first used by Prof. Mr. Moeljatno and later also used by Prof. Mr. Roslan Saleh (Sjahdein, 2017). The criminal offense is taken 
from the definition of a criminal act in English. In Dutch, apart from using the term delict, the term strafbaar feit is also used, while the terms used in English are crime, offense, or criminal conduct (Sjahdein, 2017).

A child who commits a criminal act can be called a child in conflict with the law. Article 1 point 3 of Law Number 11 of 2012 concerning the Criminal Justice System for Children states that: Children in conflict with the law after this referred to as Children, are children who have reached the age of 12 (twelve) years but are not yet 18 (eighteen) years old-suspected of committing a criminal act.

One of the criminal acts committed by children is the act of rape involving elementary and junior high school children as quoted in detik.com as follows:

Probolinggo: An elementary and junior high school student has to deal with the police. They reportedly raped a high school student and became pregnant. The victim has now given birth. The two perpetrators were residents of Probolinggo Regency. The perpetrator's actions have been carried out since a year ago. "This victim is still related to the junior high school perpetrator. The victim has lived in the middle school's parents' house since she was a child," said Probolinggo Police Chief AKBP Eddwi Kurniyanto to detikcom, Monday (4/15/2019). $M$ is the victim's cousin. Even though he is 18 years old, $M$ himself is still in junior high school because he failed to grade several times. Meanwhile, the perpetrator, who is still in elementary school, is 13 years old. Eddwi said the victim was raped for the first time in April last year. The victim was initially raped by $M$, a junior high school perpetrator. The victim's refusal ended in vain because $M$ threatened to evict her parents' house if the victim refused her request. Another time, $M$ repeated his actions. However, this time $M$ asked his friend, who was still in elementary school, to rape the victim. The third and subsequent acts were carried out simultaneously, and some were carried out by elementary school actors alone. The act was carried out at M's house when it was quiet. The rape eventually made the victim pregnant. The victim who claimed to be pregnant made the perpetrators afraid and did not rape the victim again. "The perpetrator raped the victim about five times until the victim became pregnant. Moreover, the family just found out that the perpetrator was $M$ and her elementary school friend," said Eddwi. Police who received complaints from residents immediately took action. The police immediately arrested the two perpetrators suspected of having committed the crime of rape of minors. "The perpetrator is threatened with Article 76 D Jo Article 81 of the Republic of Indonesia Law, number 35 of 2014 concerning the protection of women and children. With the threat of a sentence of 15 years in prison. However, we will coordinate again with the district attorney because the perpetrators are also underage," he said. Eddwi.

Sexual crime against minors committed by children (perpetrators) occurs in many countries. Sexual crimes against children occur in Southeast Asian countries, such as the Philippines, Thailand, Sri Lanka, Malaysia, and Indonesia. In psychology, the transition period experienced by children from the age of 10 years, in his book Sudarsono agrees with Andi Mapiere, who quotes Elisabeth B. Harlock, who divides the age of adolescents, namely puberty at the age of 10 years or 12 years to 13 years or 14 years, adolescence at the age of 13 or 14 years to 17 years, the final period (adulthood) at the age of 17 years to 21 years (Sidabalok \& Hosianna, 2012).

Article 1 point 6 of Law Number 11 of 2012 concerning the Restorative Justice Child Criminal Justice System is the settlement of criminal cases by involving perpetrators, victims, families of perpetrators/victims, and other related parties to jointly seek a fair solution by emphasizing recovery return to its original state, and not retaliation.

In principle, the juvenile criminal justice system Law puts forward the Restorative Justice approach and the diversion process as an effort to resolve criminal acts committed by children, so that the application of Restorative Justice will offer answers to essential issues in solving criminal cases, namely; first, criticism of the criminal justice system which does not provide opportunities, especially for victims (criminal justice system that disempowers individuals), second, 
eliminating conflicts, especially between the perpetrator and the victim and society (taking away the conflict from them); third, the fact that feelings of helplessness experienced as a result of criminal acts must be overcome in order to achieve improvement (Ernis, 2016). According to Muladi, Restorative Justice or restorative justice is a theory that emphasizes restoring losses caused or incurred by criminal acts. Recovering this loss will be achieved by cooperative processes that include all interested parties (Utami, 2018).

Several studies have examined similar titles, including; First, the research entitled the mechanism for prosecuting children at the Semarang state prosecutor's office, but only reviews the scope of the prosecution mechanism for child crimes committed by the Semarang Public Prosecutor and the efforts that must be pursued using Diversi that lead to kinship, (Sulchan \& Ghani, 2017); Second, the research entitled juvenile (In) justice: children in conflict with the law in Indonesia explains that Indonesia has failed to follow up on its various commitments regarding children. This failure not only shows the difficulty in influencing change in a country that is very diverse with systemic corruption and poverty but suggests concern in Indonesia to present a positive public image above substantially improving the lives of children in conflict with the law (Davies \& Robson, 2016). and Third, a study entitled Child Rights, Poverty, and Protection: An Indian perspective explaining the principles contained in the ILO Minimum Age Convention No. 138 and Worst Forms of Child Labor Convention No. 182, ILO Focus Program on Child Labor (IPEC) working to achieve child labor, aims to delineate gaps and opportunities to reform "Legislation, Systems and Mechanisms" relating to the limitation of "Child Labor in India" and call for partnerships for development towards this vicious problem (Palanichamy, Child Rights, Poverty and Protection: An Indian perspective, 2016).

\section{LITERATUR REVIEW}

We already know that children's criminal acts are called children in conflict with the law, which is one of the definitions of children in conflict with the law. Article 1 paragraph (2) of the juvenile criminal justice system Law Number 11 of 2012 that children in conflict with the law mean is as follows: "Children in conflict with the law are children in conflict with the law, children who are victims of criminal acts, and children who are witnesses of a crime."
According to the provisions of Article 1 paragraph (3) of the juvenile criminal justice system Law Number 11 of 2012, the age limit for children in conflict with the law, namely: eighteen) years who are suspected of committing a criminal act." The provisions of Article 3 of the juvenile criminal justice system Law clearly states the rights of children in criminal justice, namely: (1) Treated humanely with attention to the needs according to age; (2) Is separated from adults; (3) Obtain legal aid and other assistance effectively; (4) Conducting rational activities; (5) Free from torture, punishment, or other cruel, inhuman, and degrading treatment of dignity and status; (6) Not sentenced to death or life imprisonment; (7) Not arrested, detained, or imprisoned, except as a last resort and for the shortest time; (8) Obtaining justice before the Juvenile Court that is objective, impartial, and in sessions closed to the public; (9) Identity is not published; (10) Obtain assistance from parents/guardians and people trusted by the child; (11) Obtain social advocacy; (12) Obtaining personal life; (13) Obtain accessibility, especially for children with disabilities; (14) Obtaining education; (15) Obtain health services; and; (16) Obtain other rights by the provisions of laws and regulations.

After knowing what is meant by children's criminal acts, we will discuss restorative justice. Restorative justice is the process of resolving acts of legal violations that have occurred, which is carried out by bringing the victim and the perpetrator (suspect) together to sit in a meeting to talk together, in that meeting the mediator provides an opportunity for the perpetrator to provide a clear picture of actions he has done. The perpetrator who gave the presentation expected the victim to be able to accept and understand the conditions and causes why the perpetrator committed a criminal act that caused the victim to suffer losses. Then the perpetrator also explained his responsibility for the act he had committed. Then the victim responded to this, and besides that also attended by the community as parties who were also disadvantaged in general (Marlina, 2009). So the Restorative justice approach offers the settlement of criminal cases involving children, it is sufficient to resolve through mediation between the perpetrator, the victim, and the community as the party who is the victim as well as the party who must be responsible for the behavior of the child as the perpetrator of the crime, because the community or parents are the ones who should be the party most responsible for the child's actions. Because often, 
children commit these crimes after previously "learning" from their parents or society (Marlina, 2009).

In short, the discourse on child protection says that a child is a young human being at a young age, in a young soul and on the way to being easily influenced by circumstances around him, that means that in such circumstances, it demands law to behave "special" towards children and the settlement of children's cases. Outside the court and anti-imprisonment is the answer (Sukoco, 2016).

Susan Sharpe, in her book "Restorative Justice a Vision For Hearing and Change" states that there are 5 (five) principles in restorative justice, namely (Hutauruk, 2013): (1) Restorative justice invites full participation and consensus. Restorative justice contains full participation and consensus. In this case, victims and perpetrators are actively involved in negotiations to find a comprehensive solution. Apart from that, it also opens up opportunities for people who have been disturbed by their security and order by the perpetrators to sit together to solve the problem. Invitations to participate are not binding/mandatory, only voluntary, although of course the perpetrator will be included; otherwise, the traditional justice process will take place; (2) Restorative justice seeks to heal what is broken. Restorative justice seeks a solution to restore and heal the damage or loss resulting from a criminal act committed by the perpetrator. This includes efforts to heal or treat the victim for the crime that befell him. However, perpetrators also need healing; they need to be freed from their guilt and fear; (3) Restorative justice full sex and direct accountability. Restorative justice provides a complete sense of responsibility for the perpetrators who are responsible for their actions. The perpetrator must show his regret and admit his mistakes and realize that his actions are causing harm to others ; (4) Restorative justice seeks to recite what has been confirmed. Restorative justice tries to reunite the perpetrators as community members and their communities who have been separated due to criminal acts. This is done by holding reconciliation between the victim and the perpetrator and reintegrating them into everyday community life. Both must be freed from their past for a brighter future and; (5) Restorative justice seeks to strengthen the community in order to prevent further harm. Restorative justice provides the power to the community to prevent crimes from happening again. Crime wreaks havoc on people's lives, but crime can be a lesson for society to open true justice for all people.
The characteristic of restorative justice is that it makes the offender responsible for repairing the losses caused by his mistake; provide an opportunity for offenders to prove their capacity and quantity in addition to dealing with guilt constructively; involving victims, parents, extended family, school, and close friends; creating a forum to work together in solving the problem; establish a direct and real relationship between mistakes and social reactions. In children's best interest, law enforcement officials should apply a restorative justice approach (Laksana, 2017).

Indicators in restorative juvenile justice can be seen from the roles of perpetrators, victims, the community, and juvenile justice professionals. Each role is as follows (Angkasa \& et al., 2009): (1) Perpetrators, active actors to restore losses to victims and society. $\mathrm{He}$ must face the victim/victim's representative; (2) Victims are actively involved in all stages of the process and play an active role in mediation, and participate in determining sanctions for the perpetrators; (3) The community is involved as a mediator in developing community services and providing job opportunities for the perpetrators as a form of reparative obligation, helping victims and supporting the fulfillment of the perpetrators' obligations and; (4) Professionals facilitate mediation, guarantee restorative implementation, develop creative/restorative community service options, involve community members in the process, educate the community.

In its application, not all cases of children can be subject to restorative justice, and the criteria are as follows, not a case of child delinquency which sacrifices the interests of many people, the delinquency of the child which does not result in loss of human life, severe injury or lifelong disability and the delinquency does not constitute a crime against decency which serious about honor and not a traffic offense.

Restorative justice is an effort to seek peaceful conflict resolution outside the court. Especially for children with legal conflicts, restorative justice is necessary because child psychological factors must be considered. There are four criteria for cases of children dealing with the law that can be resolved using a restorative justice model, namely (Angkasa \& et al., 2009): (1) The case does not sacrifice the public interest and is not a traffic violation; (2) The child is doing delinquency for the first time and is not a recidivist; (3) The case is not a case that results in the loss of human life, serious injury, or life disability and; (4) The case does not constitute a severe honor crime. 


\section{METHODS}

This study using a normative juridical research type. The definition of normative juridical is a type of research that emphasizes more on library research, where the materials used will be obtained from laws, literature, mass media, which are related to writing materials. The author will also describe the data obtained from the literature in the results of this study. After obtaining data using normative juridical, the authors describe in words in the study entitled the restorative justice approach to resolve the crime of rape with child perpetrators (Riyanto, 2016).

The analytical method used refers to the law, existing regulations, looking at the existing legal principles and concepts of child crime, explaining the regulation of child criminal acts, and tracing the approaches to children through restorative justice. Normative juridical research is needed because it is necessary to make an inventory of positive law, the discovery of the principles and basic philosophy (dogma or doctrine) of positive law; and in-concreto legal findings that are feasible to be applied to resolve a particular legal case (Noho, 2019).

How to collect data used in a study depends on the scope and objectives of the study. According to Ronny Hanitijo Soemitro (1990), data collection techniques consist of literature study, observation, interview, and use of questionnaires. Based on the scope, objectives, and approach in this study, the data collection technique used is a literature study of the secondary data analyzed. The secondary data obtained will be used to support the analysis in this study.

\section{RESULTS AND DISCUSSION}

\section{The Importance of Restorative Justice Approach in Resolving Child Crimes in Indonesia}

The juvenile justice system in Indonesia, which currently has become the basis of the spirit in the Draft Criminal Code, which among other things changes the paradigm, among others: The objective of the punishment is to "resolve conflicts caused by criminal acts, restore balance and bring a sense of peace to the community; the spirit of concern for victims of crime; development of an alternative to criminal independence (alternative to imprisonment); specifically the provisions of crimes and actions for children. Apart from the Criminal Code Bill, it is also the juvenile criminal justice system Law, which has put efforts into diversion and restorative justice (Muladi, 2013). In Indonesia, to resolve criminal acts committed by children based on Law Number 11 of 2012 concerning the Juvenile Criminal Justice System (Law juvenile criminal justice system). Law SPPA is interesting because it includes restorative justice efforts in it.

Probolinggo, as one of the regions in Indonesia that protect and protect children from committing criminal acts, also has cases in that area. According to the Child Protection Agency National Human Rights Commission, Representative of the City / Regency of Probolinggo, it was noted that during 2015-2020 (until October), 3,060 children experienced violence. Among them are sexual abuse and violence against children; both the perpetrators are children and adults. This number increased 20 percent over the previous year.

Special attention to the restorative justice process among children is needed because there are essential things to focus on the regulation that requires the active role of the community, perpetrators, and victims of crime, including the affected communities, in the restorative justice process. A basic balancing approach must also be carried out, namely, imposing sanctions based on responsibility for recovering victims' losses due to criminal acts; second, rehabilitation and reintegration of actors; and third, strengthening community safety and security systems. The shift in the "juvenile justice system," which is punitive and retributive and emphasizes the mission of fostering perpetrators solely that fail towards a balanced approach between perpetrators, victims and society is very rational because all three are clients of the justice system.

Furthermore, in the juvenile justice system, the balanced approach must be utilized which can meet the needs of the community, for perpetrators (children) who, after going through the restorative process, are expected to be more able to integrate with society than before; and the value of community protection (community protection), because the restorative justice system is responsible for protecting society from criminal acts of children through peaceful means (Muladi, 2013).

The main purpose of restorative justice is to reparation for victims' losses, recognition of perpetrators for losses due to crimes committed, conciliation or reconciliation between victims, perpetrators, and society, reintegration of perpetrators, and through peaceful conflict resolution (peacefully resolved), community security can be managed 
Table 1: Differences between Retributive and Restorative Justice

\begin{tabular}{|c|c|c|c|}
\hline No & The Main Theme of Justice & Retributive & Restorative \\
\hline \hline 1. & Justice orientation & To Offenders and for their violations & Violating individual rights \\
\hline 2. & Crime & Breaking the State & $\begin{array}{c}\text { The person is directly injured, the } \\
\text { community, the State and the } \\
\text { perpetrators themselves }\end{array}$ \\
\hline 3. & Victim & Country & $\begin{array}{c}\text { Resolving conflicts between offenders } \\
\text { and victims }\end{array}$ \\
\hline 4. & Criminal Justice System & $\begin{array}{c}\text { Trying offenders and punishing a } \\
\text { rationalization of retaliation }\end{array}$ & $\begin{array}{c}\text { Offenders' responsibility for the } \\
\text { consequences of their actions }\end{array}$ \\
\hline 5. & Criminalization & $\begin{array}{c}\text { Criminal is like retaliation for violations of } \\
\text { criminal law }\end{array}$ & Passive \\
\hline 6. & Victims in the Criminal Justice & System & Pave
\end{tabular}

(Muladi, 2013). Fairness in restorative justice is not justice, which means imposing a sentence by the perpetrator's actions, but a justice known as restorative justice. Restorative justice is a process that involves collectively how to deal with the consequences of a crime with future implications. The restorative justice approach is a justice process entirely carried out and achieved by the community (Mulyadi, 2014).

Besides, special attention to the restorative justice process among adolescents is needed because there are important things to focus on regulation that requires the active role of the community, perpetrators, and victims of crime, including the affected communities in the restorative justice process. A fundamental balancing approach must also be taken, namely, first, imposing sanctions based on responsibility for recovering victims' losses as a consequence of criminal acts; second, rehabilitation and reintegration of actors; and third, strengthening community safety and security systems. The shift in the "juvenile justice system," which is punitive and retributive and emphasizes the mission of fostering perpetrators solely that fail towards a balanced approach between perpetrators, victims and society is very rational because all three are clients of the justice system. Isolating the perpetrators of criminal acts will weaken the "community bond," which will create more crimes. Adolescence requires the need to be owned and cared for rather than isolated. Adolescents have an attachment to a unique environment such as school, employment, religious life, and recreation areas with a lifestyle in clothing, music, language, Etc. Disconnecting from the environment because of suspicion, worry, or fear of juvenile criminals, coupled with a retributive approach to punishing and taking action, will lead to criminal acts and further violence. For that, we need a new "juvenile justice" with a mission-based on values, goals, policies, and new programs (paradigm shift) that are expected to be more productive, more responsive, and more effective in means three interests (perpetrators, victims, and society). "Mutual responsibility" between the three will strengthen community building and break the isolation and lack of relationship between youth and society (Nasional, 2013).

Not only that, for the sake of maintaining public peace and order, it is not an exaggeration and nothing extraordinary if our justice system is shifted from retributive justice to restorative justice or restorative justice. The differences between retributive and restorative justice, as stated by Mahmud Mulyadi, are as follows (Sukoco, 2016):

\section{Restorative Justice Approach as an Effort to Settle the Crime of Rape with Child Offenders}

According to The Child Protection Agency, National Human Rights Commission, City / District of Probolinggo, the criminal case of rape was the most cases during 2015-2020 (until October), namely 1200 cases, where the perpetrator was children and adults. Among the cases of rape in which the perpetrator is a child can be seen in these two cases. First, the rape case occurred because there were acts of violence, coercion, and threats against the victim. Second, rape cases occurred not because of violence, coercion, or threats but on a consensual basis. Although there are persuasion and trickery elements, the victim finally wants or accepts; this is called intercourse (Rokamah, 2013). In the case of rape committed by $M$ and his friend, who was still an elementary school student, it occurred because of watching adult films, so that they committed rape with threats against the high school child who was still his relative.

The criminal acts committed by $\mathrm{M}$ and his friends can be resolved using the restorative justice approach 
in Law juvenile criminal justice system using diversion. The concept of Restorative Justice is not explicitly obliged in the Law, but if we look at Law Number 11 of 2012 concerning the Juvenile Criminal Justice System, the spirit of Restorative Justice can be felt the spirit of its implementation. Even though Law no. 11 of 2012 through Article 1 paragraph 6 only defines restorative justice, namely the completion of the word of crime by involving the perpetrator, the victim, the family of the perpetrator/victim, and other related parties to jointly seek a fair solution by emphasizing restoration to its original state, and not retaliation (Kustrini, 2015). Diversion is a joint deliberation step in this case from both the perpetrator and the victim, but still in every stage of the judicial process (Purnomo, Gunarto, \& Purnawan, 2018).

A diversion process can carry out $\mathrm{M}$ and his friends' actions because the diversion process that uses the restorative justice approach is used in children whose criminal threats are under 7 (seven) years and are not a repetition (Article 7). Whereas the threat of punishment $\mathrm{M}$ and his friends, according to Article 76D jo Article 81 of the Law of the Republic of Indonesia Number 35 of 2014 concerning Amendments to Law Number 23 of 2002 concerning Child Protection, shall be punished with imprisonment for a minimum of 5 (five) years and a maximum of 15 (fifteen) years and a maximum fine of Rp. $5,000,000,000.00$ (five billion rupiah). In the process of enforcing juvenile criminal Law, officials, whether investigators, public prosecutors, and judges in conducting diversion, must consider the categories of criminal acts, the child's age, the results of social research from BAPAS, and the support of the family and community environment.

The existence of the restorative justice process as an alternative to solving criminal cases is very much determined by the awareness and knowledge of the community itself, including law enforcement officials. Understanding the judiciary that only puts forward the application of rules to prove the wrongdoers and then punishes them will not accept this concept. For him, the judiciary is the state's right to impose sanctions on its citizens who have violated the rules. Determination and rehabilitation is a very populist factor in it; the judiciary's attention is dominated by the interests of the perpetrators, society, and the state. Restorative justice is about solving problems between parties in social relations rather than confronting the perpetrator and government officials. The just peace principle philosophy is integrated with the meeting, discussing, and actively resolving the criminal matter. Integration of perpetrators on the one hand and victims, society on the other hand as a unit to find solutions and return to the pattern of good relations in society (Prayitno, 2012).

Regarding the handling or settlement of cases of criminal acts of rape committed by minors, for criminal acts of rape or sexual intercourse (in terms of article 81 paragraph (2) of Law No. 23 of 2002 concerning Child Protection), the settlement can also be left to the parents of the victim or the perpetrator. This is also done because it considers child protection to grow, develop and participate optimally, as referred to in Article 1 paragraph (2) of Law no. 23 of 2002 concerning Child Protection.

We need to remember that solving criminal problems cannot be fixed in the realm of penalties because the ending of the existence of law is to punish the perpetrators of criminal acts and how the law can reconcile and reassure society. According to Rusli Muhammad, the law's long-term goal (legal system/criminal justice) is the creation of a comprehensive level of welfare among the community (Muhammad, 2014).

Several reasons it is possible to do restorative justice in this case, namely; 1) the perpetrator wants to be responsible for all his actions, namely actually marrying the victim, 2) the perpetrator regrets his actions, 3) before a case like this is returned to the family, there must be a guidance for both the perpetrator and the victim, and 4) Considered in this matter is that the victim wants or wants to make peace with the perpetrator of the crime of rape (Rokamah, 2013). In its implementation, the process of implementing restorative justice requires a desire to continue to protect child offenders. However, this is because the restorative process requires an admission of guilt (Danielt, 2014).

\section{CONCLUSIONS}

Criminal acts committed by children are called children in conflict with the law. One of the criminal acts of children in conflict with the law is the crime of rape. This can be seen in two cases that occurred in Probolingo Indonesia. This case illustrates that children's existence is not entirely a victim of rape but can be the perpetrator of rape. Restorative justice in juvenile crime is essential because there are essential things to focus on regulations that require the active role of the community, perpetrators, and victims of crime, including communities affected in the restorative 
justice process. A basic balancing approach must also be taken, namely, first, imposing sanctions based on responsibility for recovering victims' losses as a consequence of criminal acts; second, rehabilitation and reintegration of actors; and third, strengthening community safety and security systems

\section{REFERENCE}

Angkasa, \& et al. (2009). Model Peradilan Restoratif Dalam Sistem Peradilan Anak (Kajian tentang Praktik Mediasi Pelaku dan Korban dalam Proses Peradilan Anak di Wilayah Hukum Balai Pemasyarakatan Purwokerto). Jurnal Dinamika Hukum, 9 (9), 191. https://doi.org/10.20884/1.jdh.2009.9.3.230

Danielt, R. T. (2014). Penerapan Restorative Justice Terhadap Tindak Pidana Anak Pencurian Oleh Anak Di Bawah Umur. Jurnal Lex et Societatis, II (6), 24.

Davies, S. G., \& Robson, J. (2016). Juvenile (In)justice: Children in Conflict with the Law in Indonesia. Asia-Pacific Journal On Human Rights And The Law, 1 (17), 120. https://doi.org/10.1163/15718158-01701009

Ernis, Y. (2016). Diversi Dan Keadilan Restoratif Dalam Penyelesaian Perkara Tindak Pidana Anak Di Indonesia. Jurnal IImiah Kebijakan Hukum, 10 (2), 165.

Hutahaean, B. (2013). Penerapan Sanksi Pidana Bagi Pelaku Tindak Pidana Anak Kajian Putusan Nomor 50/Pid.B/2009/Pn.Btg. Jurnal Yudisial, 6 (1), 65.

Hutauruk, R. H. (2013). Penanggulangan Kejahatan Korporasi melalui Pendekatan Restoratif. Jakarta: Sinar Grafika.

Jamil, M. N. (2013). Anak Bukan untuk Dihukum. Jakarta: Sinar Grafika.

Kustrini. (2015). Penyelesaian Tindak Pidana Kesusilaan Antar Anak Dengan Pendekatan Restorative Justice. Jurisprudence, 5 (2), 84.

Laksana, A. W. (2017). Keadilan Restoratif dalam Penyelesaian Perkara Anak yang Berhadapan dengan Hukum dalam Sistem Peradilan Pidana Anak. Jurnal Pembaharuan Hukum, IV (1), 61. https://doi.org/10.26532/jph.v4i1.1644

Marlina. (2009). Peradilan Pidana anak di Indonesia: Pengembangan Konsep Diversi dan Restorative Justice. Bandung : Refika Aditama.

Maskur, M. A. (2012). Legal Protection Against Naughty Children (Juvenile Delinquency) In Indonesian Criminal Procedure Process. Pandecta, 7 (2), 172.

Muhammad, R. (2014). Sistem Peradilan Pidana Indonesia. Yogyakarta: UII Press.

Muladi. (2013). Restorative Justice dalam Sistem Peradilan Pidana dan Implementasinya dalam Penyelesaian Tindak Pidana yang dilakukan oleh Anak-Anak. Jakarta : BPHN.

Mulyadi, L. (2014). Sistem Peradilan Pidana Anak. Bandung: Alumni.
Nasional, B. P. (2013). Pengkajian Hukum Tentang Penerapan Restorative Justice Dalam Penyelesaian Tindak Pidana Yang Dilakukan Oleh Anak-Anak. Jakarta: BPHN.

Noho, M. D. (2019). Politik Hukum Pengaturan Build Operate Transfer (BOT) Di Indonesia: Di Masa Lalu, Saat Ini, Dan Akan Datang. Jurnal Hukum Media Bhakti, 3 (1), 90. https://doi.org/10.32501/jhmb.v3i1.51

Palanichamy, A. (2016). Child Rights, Poverty and Protection: An Indian perspective. Journal On Rights Of The Child, 1 (1), 1.

Palanichamy, A. (2016). Child Rights, Povertyand Protection: An Indian perspective. Journal On Rights Of The Child, 1 (1), 1.

Pramukti, A. S., \& Primaharsya, F. (2014 ). Sistem Peradilan Pidana Anak. Yogyakarta: Mediapress Digital.

Prayitno, K. P. (2012). Restorative Justice Untuk Peradilan Di Indonesia (Perspektif Yuridis Filosofis Dalam Penegakan Hukum In Concreto). Jurnal Dinamika Hukum, 12 (3), 413. https://doi.org/10.20884/1.jdh.2012.12.3.116

Purnomo, B., Gunarto, \& Purnawan, A. (2018). Penegakan Hukum Tindak Pidana Anak Sebagai Pelaku Dalam Sistem Peradilan Pidana Anak (Studi Kasus Di Polres Tegal). Jurnal Hukum Khaira Ummah, 13 (1), 49.

Riyanto, A. (2016). The Existence and Legal Position of the Chief of Police Circular Regarding the Handling of Hate Speech. Journal of the Light of Justice, 3.

Rokamah, R. (2013). Restorative Justice Bagi Anak Pelaku Tindak Pidana Perkosaan Anak Perspektif Hukum Islam Dan Hukum Positif. Jurnal justitia Islamica, 10 (2), 277. https://doi.org/10.21154/justicia.v10i2.150

Saharuddin. (2014). Legal Protection of Children as Perpetrators of Murder (Case Study of Decision No: 164 / Pid.B / 2009 / PN.PL). Legal Opinion Law Studies, 2 (6), 3.

Sidabalok, M., \& Hosianna. (2012). Perlindungan Hukum terhadap Anak Korban Tindak Pidana Pemerkosaan yang Dilakukan oleh Anak. Majalah Hukum Varia Peradilan, XXVII (325), 2.

Sjahdein, S. R. (2017). Ajaran Pemidanaan: Tindak Pidana Korporasi dan Seluk Beluknya. Depok: Kencana.

Soemitro, R. H. (1990). Metodologi Penelitian Hukum dan Jurimetri. Jakarta: Ghalia Indonesia

Sukoco, B. (2016). Pendekatan Restoratif Justice Sebagai Upaya Penyelesaian Cybercrime Dengan Pelaku Anak (Studi Kasus Penyelesaian Tindak Pidana Anak Usia Sekolah). Jurnal Law and Justice, 1 (1), 60. https://doi.org/10.23917/laj.v1i1.2859

Sulchan, A., \& Ghani, M. G. (2017). The Mechanism of Prosecuting the Public Prosecutor for the Crime of Children. Ulul Albab: Study and Research of Islamic Law, 1 (1), 114. https://doi.org/10.30659/jua.v1i1.2218

Supramono, G. (2010). Hukum Acara Pengadilan Anak. Jakarta: Djambatan.

Utami, P. R. (2018). Konsep Diversi Dan Restorative Justice Sebagai Pergeseran Tanggung Jawab Pidana Pada Sistem Peradilan Pidana Anak. Jurnal Volkgeist, 1 (1), 97. https://doi.org/10.24090/volksgeist.v1i1.1691

https://doi.org/10.6000/1929-4409.2021.10.69

(c) 2021 Sulistyo et al.; Licensee Lifescience Global.

This is an open access article licensed under the terms of the Creative Commons Attribution Non-Commercial License (http://creativecommons.org/licenses/by-nc/3.0/) which permits unrestricted, non-commercial use, distribution and reproduction in any medium, provided the work is properly cited. 